\title{
Decomposition of the remaining straw during soybean growing in the midwestern Paraná, Brazil
}

\author{
Gustavo Soares Wenneck ${ }^{1}$, Reni Saath ${ }^{1}$, Larissa Leite de Araujo ${ }^{1}$, Gustavo Lopes Pereira ${ }^{1}$, \\ Roberto Rezende ${ }^{1}$, Guilherme Soares Wenneck ${ }^{1}$ \\ ${ }^{1}$ Universidade Estadual de Maringá, Campus Maringá, Maringá, Paraná, Brasil. E-mail: gustavowenneck@gmail.com, \\ rsaath@uem.br, larissa_leite_araujo@hotmail.com, gustavolopespereira@hotmail.com, rrezende@uem.br, \\ guilhermesoareswenneck@gmail.com
}

Received: 20/07/2021; Accepted: 19/08/2021.

\section{ABSTRACT}

Crop biomass plays an important role, especially in tropical and subtropical crops that adopt the no-tillage system, whose decomposition is related to material composition and environmental conditions. The objective of this work was to analyze the decomposition of straw remaining from autumn/winter crops in the development of soybean in succession in the Midwest region of Paraná. The experiment was conducted between 2019 and 2021 in a completely randomized design, with eight treatments (spontaneous, black oat, brachiaria, corn, wheat, oilseed radish, corn + brachiaria, and black oat + oilseed radish) and four replications. After autumn/winter cultivation, biomass samples were dried and placed in nylon bags, returning to the original plot during soybean sowing. The decomposition bags were collected in seven periods over 120 days, coinciding with the soybean cycle. The decomposition rate was analyzed by regression. The regression equations and the amount of biomass remaining from the autumn/winter seasons were determinate the half-file and the remaining mass on the soil surface at sowing and at 30,60,90, and 120 days after sowing. Biomass production and decomposition rate varied with the season, depending on environmental conditions. Wheat had the lowest decomposition rate with a half-life greater than 100 days. Intercropping crops reduce the decomposition rate.

Keywords: Land cover, organic matter, no-tillage system, agricultural systems, cultural remains.

\section{Decomposição da palhada remanescente durante o desenvolvimento da soja na região centro- oeste do Paraná, Brasil}

\section{RESUMO}

A biomassa das culturas tem papel importante, principalmente em lavouras tropicais e subtropicais que adotam o sistema de semeadura direta, cuja decomposição está relacionada a composição do material e condições ambientais. O objetivo do trabalho foi analisar a decomposição da palhada remanescente de cultivos outono/inverno no desenvolvimento da soja em sucessão na região centro-oeste do Paraná. O experimento foi conduzido entre 2019 e 2021 em delineamento inteiramente casualizado, com oito tratamentos (espontâneas, aveia-preta, braquiária, milho, trigo, nabo-forrageiro, milho + braquiária e aveia-preta + nabo) e quatro repetições. Após o cultivo outono/inverno amostras da biomassa foram secas e acondicionadas em bolsas de nylon retornando a parcela de origem, na semeadura da soja. As bolsas de decomposição foram coletadas em sete períodos durante 120 dias, coincidindo com o ciclo da soja. A taxa de decomposição foi analisada por regressão. A partir das equações de regressão e quantidade de biomassa remanescente dos cultivos outono/inverno foi determinado o tempo de meia vida e a massa remanescente sobre a superfície do solo na semeadura e aos 30, 60, 90 e 120 dias após a semeadura. A produção de biomassa e a taxa de decomposição foi variável com a safra, em função das condições ambientais. O trigo apresentou a menor velocidade de decomposição com tempo de meia vida superior a 100 dias. Cultivos consorciados reduzem a taxa de decomposição.

Palavras-chave: Cobertura de solo, matéria orgânica, sistema plantio direto, sistemas agrícolas, restos culturais. 


\section{Introduction}

The organic matter in the soil in agricultural systems comes from plant residues, with variable quality and composition depending on the species and cultivation characteristics, generating physical, chemical, and biological benefits for the productive environment (Cunha et al., 2015; Ramos et al., 2018; Bonetti e Fink, 2020). Soils managed in a no-tillage system have greater organic carbon and microbial biomass, reducing degradation (Feitosa Júnior et al., 2019).

The speed of decomposition depends on the composition of the material, such as lignin, cellulose, pectin, and mainly on the carbon/nitrogen $(\mathrm{C} / \mathrm{N})$ ratio, the ratio is inversely proportional to the rate of decomposition (Kliemann et al. 2006; Teixeira et al., 2011; Rossi et al., 2013; Ramos et al., 2018). The composition also influences the water absorption capacity (Silva et al., 2019), being an essential factor for the action of microorganisms.

The supply of nutrients from the remaining biomass may be greater than the crop cycle in succession, with different decomposition rates and half-life of the remaining straw according to the species (Cavalli et al., 2018; Comin et al., 2018; Ramos et al., 2018). The remaining biomass may present different decomposition rates depending on the intrinsic characteristics of the material and the environment. In this sense, the study aimed to analyze the decomposition rate of biomass formed in autumn/winter crops during soybean cultivation (crop 2019/2020 and 2020/2021) in succession in the Midwest region of Paraná, Brazil.

\section{Material and Methods}

The experiment was carried out in a cultivation area under a no-tillage system, at São José farm (2359'11.63" S, 52²9'52.02" W and altitude of 535 $\mathrm{m})$ in Campo Mourão-PR, whose conditions of average annual temperature and rainfall are $19.9^{\circ} \mathrm{C}$ and 1.570 $\mathrm{mm}$, respectively. The climate of the region is classified as Cfa (Köppen, 1948) with a subtropical climate, with temperatures above $22^{\circ} \mathrm{C}$ in the summer and rainfall greater than $30 \mathrm{~mm}$ in the driest month (Nitsche et al., 2019). The rainfall and temperature data during the evaluation period collected at the meteorological station of INMET, in Campo MourãoPR, are shown in Table 1.

The soil in the area is classified as LATOSSOLO VERMELHO distrófico, equivalent to Oxisol in the Soil Taxonomy (SANTOS et al., 2018), with medium texture (46\% clay) and $3.5 \%$ of organic matter. The experiment was carried out between March 2019 and March 2021 in a completely randomized design with eight treatments (Table 2), totaling four harvests, two in the autumn/winter season (second crop) and two in the summer season (first crop). The experimental plots had a total area of $20.25 \mathrm{~m}^{2}$ and a useful area of $9 \mathrm{~m}^{2}$, referring to the center of the plot.

In the implementation of autumn/winter crops, wheat sowing (Gralha Azul cultivar) was carried out with a spacing of $0.2 \mathrm{~m}$ between rows, while other crops were carried out with a spacing of $0.4 \mathrm{~m}$ between rows. For the configuration of the intercropping, in the cultivation of black oat intercropped with oilseed radish, the sowing was in intercropped rows, and in the intercropping of corn with brachiaria ruziziensis, the grass was sown between the corn rows. Seeds of black oat cultivar EMBRAPA 90 and corn hybrid Pioneer 3707 VYH were used. The soil fertility management was carried out considering the soil nutrient content at the beginning of each season and the technical recommendations for the crops as described by Pauletti and Motta. (2017).

At the end of the autumn/winter seasons, crop biomass samples were collected and sent to the laboratory of medicinal plants and post-harvest technology at the State University of Maringá (UEM). In the laboratory, they were subjected to drying in an oven with forced air circulation $\left(65^{\circ} \mathrm{C} / 72\right.$ hours) to determine the biomass yield.The dry biomass was placed in the decomposition bags in the amount of 10 $\mathrm{g}$ of dry mass per package, being the mass determined on an analytical balance $( \pm 0.001 \mathrm{~g})$. The decomposition bags were made of nylon with $10 \times 15$ $\mathrm{cm}$ dimensions and a mesh opening of $4 \mathrm{~mm}$. The decomposition bags ( 8 per plot) were distributed in the original plots on the day of soybean sowing.

Sowing of soybean, cultivar BRS 511 in the 2019/2020 harvest and M6410 2020/2021 harvest was carried out with row spacing of $0.45 \mathrm{~m}$ and population density of 311 thousand $\mathrm{pl} \mathrm{ha}{ }^{-1}$. The decomposition bags distributed in the soybean sowing were collected with an interval of 15 days until harvest. The collected samples (decomposition bags) were sent to the UEM laboratory, where foreign materials were removed (soil, insects, and different materials from the respective straw). The remaining straw in the bag was dried in an oven with forced air circulation $\left(105^{\circ} \mathrm{C} / 24\right.$ hours $)$ and weighed on an analytical balance $( \pm 0.001 \mathrm{~g})$ to determine the remaining content of straw in the bag.

Regression analysis was performed from the content remaining in the decomposition bags to estimate the decomposition rate during the soybean cycle. The remaining biomass of the predecessor crops presented in the soybean crop at sowing and 30, 60, 90, and 120 days after sowing was estimated Considering the regression equations and the biomass present at the end of the autumn/winter season. For data analysis, SISVAR (Ferreira, 2019) and Microsoft Excel $^{\circledR}$ software were used. 
Table 1. Average monthly temperature and monthly rainfall accumulated in 2019, 2020, and 2021 in Campo Mourão-PR, Brazil.

\begin{tabular}{ccccccc}
\hline \multirow{2}{*}{ Month } & \multicolumn{3}{c}{ Average temperature $\left({ }^{\circ} \mathrm{C}\right)$} & \multicolumn{3}{c}{ Accumulated rainfall $(\mathrm{mm})$} \\
\cline { 2 - 6 } & 2019 & 2020 & 2021 & 2019 & 2020 & 2021 \\
\hline January & - & 25.90 & 24.57 & - & 173.95 & 403.25 \\
February & - & 24.08 & 25.20 & - & 74.87 & 76.98 \\
March & 23.84 & 26.51 & 26.28 & 124.12 & 32.84 & 136.19 \\
April & 23.98 & 24.36 & - & 59.97 & 37.84 & - \\
May & 21.13 & 19.44 & - & 137.91 & 80.12 & - \\
June & 20.10 & 20.36 & - & 23.71 & 136.23 & - \\
July & 19.35 & 19.73 & - & 15.90 & 44.87 & - \\
August & 21.50 & 19.84 & - & 4.93 & 166.86 & - \\
September & 25.08 & 27.20 & - & 55.44 & 18.55 & - \\
October & 28.09 & 27.02 & - & 73.13 & 48.63 & - \\
November & 26.14 & 26.77 & - & 146.78 & 66.85 & - \\
December & 24.74 & 24.98 & - & 246.00 & 226.65 & - \\
\hline
\end{tabular}

Source: SISDAGRO/INMET, 2021.

Table 2. Experimental scheme of species grown in the 2019/2020 and 2020/2021 harvests, Campo Mourão-PR, Brazil.

\begin{tabular}{ccc}
\hline & Autumn/winter season & Summer season \\
\hline System & Species & Soybean \\
Fallow & Spontaneous & Soybean \\
Single & Black oat (Avena sativa) & Soybean \\
Single & Brachiaria (Urochloa ruziziensis) & Soybean \\
Single & Corn (Zea mays) & Soybean \\
Single & Wheat (Triticum spp.) & Soybean \\
Single & Oilseed radish (Raphanus sativus) & Soybean \\
Intercropping & Corn + brachiaria & Soybean \\
Intercropping & Black oat + Oilseed radish & \\
\hline
\end{tabular}

\section{Results and Discussion}

The decomposition showed significant differences $(\mathrm{p}<0.05)$ in the sampling intervals. The parameters of the equation and the half-life of remaining straw from Autumn/Winter crops (2019) on soybean (2019/2020) are shown in Table 3.

The equation of the remaining straw decomposition (Tables 3 and 4) allows analyzing the interaction of the material with the environment and defining strategies for soil cover management. In tropical and subtropical regions, the remaining straw act protecting the soil surface, softening the temperature variation of the soil, reducing the evapotranspiration, keeping moisture in the surface zones, providing nutrients to the crops with mineralization of organic matter, and acting in the stabilization of soil aggregates (Torres et al., 2008; Tavares et al., 2015; Bueno e Rodrigues, 2019; Bonetti e Fink, 2020). The parameters of the regression equations and half-life of autumn/winter residues (2020) in soybean (2020/2021) are presented in Table 4.

The half-life time is an essential data of comparison among species and among harvests. It is possible to analyze that the decomposition happened slowly in the 2020/2021 harvest concerning the $2019 / 2020$ harvest, except for the control treatment in the presence of spontaneous plants (Tables 3 and 4). In the absence of cultivation in the autumn/winter season, there is the development of native species and weeds that show variable characteristics concerning species and intensity present in the site (Comin et al., 2018), being obtained heterogeneous biomass that shows differences concerning the composition that influences the decomposition.

The amount of remaining biomass also influences the soil cover conditions, and consequently, in the decomposition process and liberation of nutrients (Teixeira et al., 2011; Cavalli et al., 2018; Ramos et al., 2018). Generally, the grasses have greater production of matter and slower decomposition (Ziech et al., 2015). The biomass remaining on the soil surface during the soybean cycle (2019/2021 harvest) is shown in figure 1 . The value at time 0 (soybean sowing day) is determined in the field, and the other values are estimated according to the equations in table 3 . 
Table 3. Parameters of the equations of dry matter decomposition of species produced in the autumn/winter season and half-life of remaining matter during soybean cultivation (2019/2020 harvest).

\begin{tabular}{cccc}
\hline Autumn/winter season & Equation & $\mathrm{R}^{2}$ & Half-life time (days) \\
\hline Spontaneous & $\mathrm{Y}=0.0006 \mathrm{x}^{2}-0.7315 \mathrm{x}+102.59$ & 0.95 & 76.71 \\
Black oat & $\mathrm{Y}=0.0031 \mathrm{x}^{2}-0.886 \mathrm{x}+101.72$ & 0.99 & 81.75 \\
Brachiaria & $\mathrm{Y}=0.0033 \mathrm{x}^{2}-1.001 \mathrm{x}+102.94$ & 0.96 & 68.22 \\
Corn & $\mathrm{Y}=0.0009 \mathrm{x}^{2}-0.6972 \mathrm{x}+101.15$ & 0.99 & 82.04 \\
Wheat & $\mathrm{Y}=0.0009 \mathrm{x}^{2}-0.5438 \mathrm{x}+97.349$ & 0.98 & 105.48 \\
Oilseed radish & $\mathrm{Y}=0.0018 \mathrm{x}^{2}-0.793 \mathrm{x}+95.88$ & 0.97 & 68.50 \\
Corn + Brachiaria & $\mathrm{Y}=0.0014 \mathrm{x}^{2}-0.7979 \mathrm{x}+100.68$ & 0.98 & 72.81 \\
Black oat + Oilseed radish & $\mathrm{Y}=0.0019 \mathrm{x}^{2}-0.6732 \mathrm{x}+97.772$ & 0.98 & 98.15 \\
\hline
\end{tabular}

Table 4. Parameters of the equations of dry matter decomposition of species produced in the autumn/winter period and half-life of remaining matter during soybean cultivation (2020/2021 harvest).

\begin{tabular}{cccc}
\hline Autumn/winter season & Equation & $\mathrm{R}^{2}$ & Half-life time (days) \\
\hline Spontaneous & $\mathrm{Y}=-0.0006 \mathrm{x}^{2}-0.7558+102.71$ & 0.94 & 66.25 \\
Black oat & $\mathrm{Y}=-0.0015 \mathrm{x}^{2}-0.3641 \mathrm{x}+97.83$ & 0.96 & 94.54 \\
Brachiaria & $\mathrm{Y}=-0.0012 \mathrm{x}^{2}-0.5396 \mathrm{x}+98.13$ & 0.95 & 76.25 \\
Corn & $\mathrm{Y}=-0.0021 \mathrm{x}^{2}-0.2382 \mathrm{x}+97.07$ & 0.94 & 103.37 \\
Wheat & $\mathrm{Y}=-0.0002 \mathrm{x}^{2}-0.4206 \mathrm{x}+100.17$ & 0.96 & 113.17 \\
Oilseed radish & $\mathrm{Y}=0.0018 \mathrm{x}^{2}-0.7327+98.98$ & 0.97 & 84.30 \\
Corn + Brachiaria & $\mathrm{Y}=-0.0014 \mathrm{x}^{2}-0.4118 \mathrm{x}+97.86$ & 0.96 & 89.17 \\
Black oat + Oilseed radish & $\mathrm{Y}=0.0020 \mathrm{x}^{2}-0.6801 \mathrm{x}+97.98$ & 0.97 & 99.89
\end{tabular}

The differences in the amount of remaining biomass of each species, cultivated in autumn/winter season, in the sowing of soybean (Figures 1 and 2) between the two analyzed harvests are associated with the climatic conditions, mainly water availability (Table 1), that limited the vegetal development, the biomass accumulation, and the yield (Torres et al., 2008). The biomass remaining on the soil surface during the soybean cycle (2020/21 harvest) is shown in Figure 2. The value at time 0 (soybean sowing day), determined in the field, and the other values estimated according to the equations are shown in Table 4

In decomposition dynamics, the speed that the residue is degraded by microbiota depends on the chemistry constitution, mainly the $\mathrm{C} / \mathrm{N}$ ratio and lignin content, and environmental conditions, mainly temperature and moisture content (Costa et al., 2015; Cunha et al., 2015). The species Urochloa brizantha had water retention in the dry matter higher than the other grasses (Silva et al., 2019), which can contribute to the activity of microorganisms and increase the decomposition rate (Rossi et al., 2013).

Among the autumn/winter crops grown mainly for soil covering, the lowest rate of remaining straw decomposition was observed in single black oat (higher half-life than 81 days) and black oat intercropped with oilseed radish (higher half-life than 98 days). In the two analyzed crops, intercropped systems (corn intercropped with brachiaria and black oat intercropped with oilseed radish) showed lower production of total biomass than corn and oilseed radish in the single cultivation (Figures 1 and 2). The intercropping can be adopted as a strategy to reduce the decomposition speed of biomass, with the implantation of plants with higher $\mathrm{C} / \mathrm{N}$ rates (Comin et al., 2018), as black oat concerning oilseed radish.

The species intended to the grain yield in the autumn/winter season, the wheat showed a lower decomposition rate, with a half-life of remaining straw of 105 days in the 2019/2020 harvest and 113 days in the 2020/2021 harvest. When evaluating the amount of remaining dry matter maintained on the soil, Sakrezenski et al. (2018) found that 30 days after the wheat harvest, 87,91\% was still present, while Aita e Giacomini (2003), evaluating at 150 days after harvest, observed the presence of $13,53 \%$ of remaining biomass.

Diniz et al. (2019), evaluating the decomposition of U. ruziziensis, found a reduction of half-dry matter at 86 days in the conventional production system and notillage, higher than the present study (68 and 76 days), with differences possibly associated with environmental conditions.Sousa et al. (2018), analyzing kinds of cover crops, found a high decomposition rate in species leaves of Gliricidia sepium (Jacq.) Walp. and Canavalia ensiformis (L.) reaching $75 \%$ at 150 days. In the conditions analyzed, the decomposition was higher than $50 \%$ to all species in a period less than 120 days (Figures 2 and 3). 


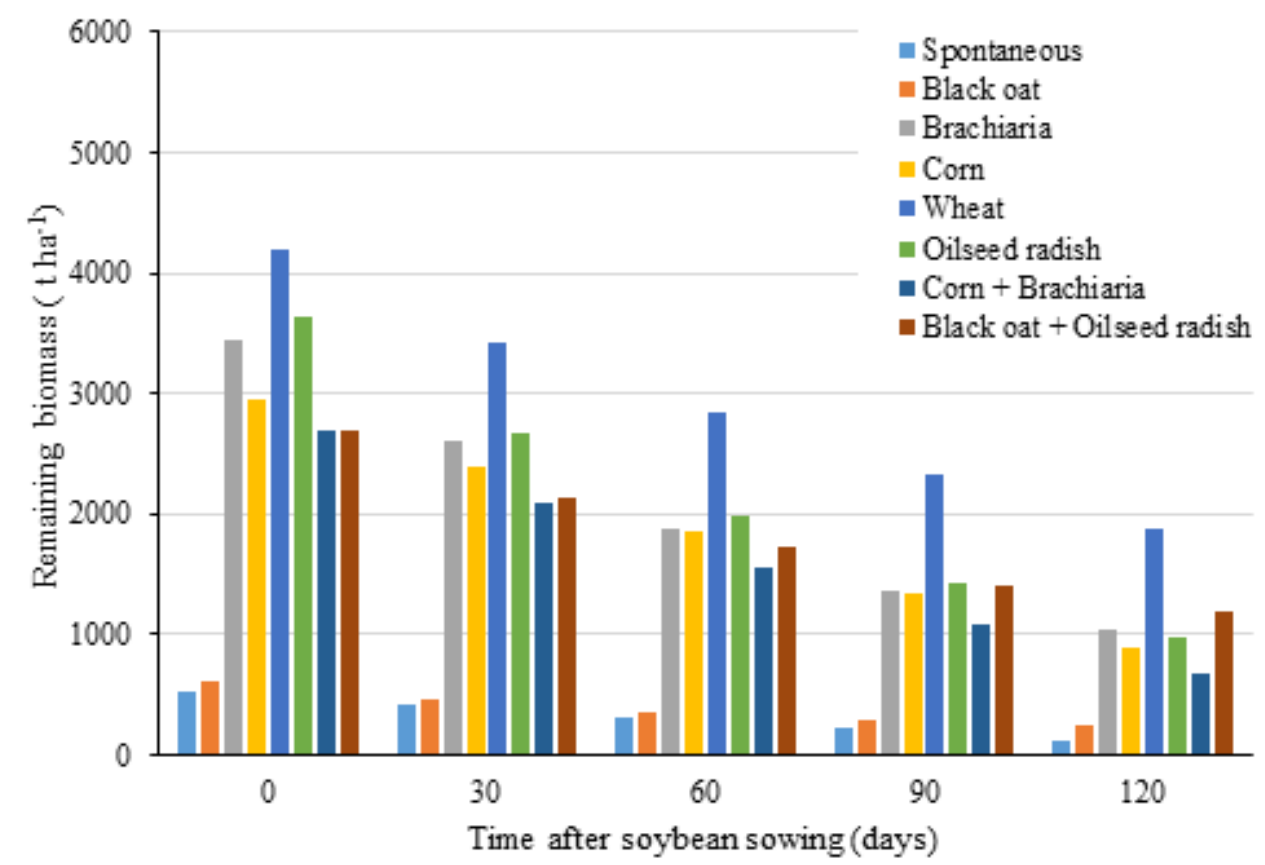

Figure 1. Straw remaining decomposition from the autumn/winter season during soybean development in the 2019/2020 harvest.

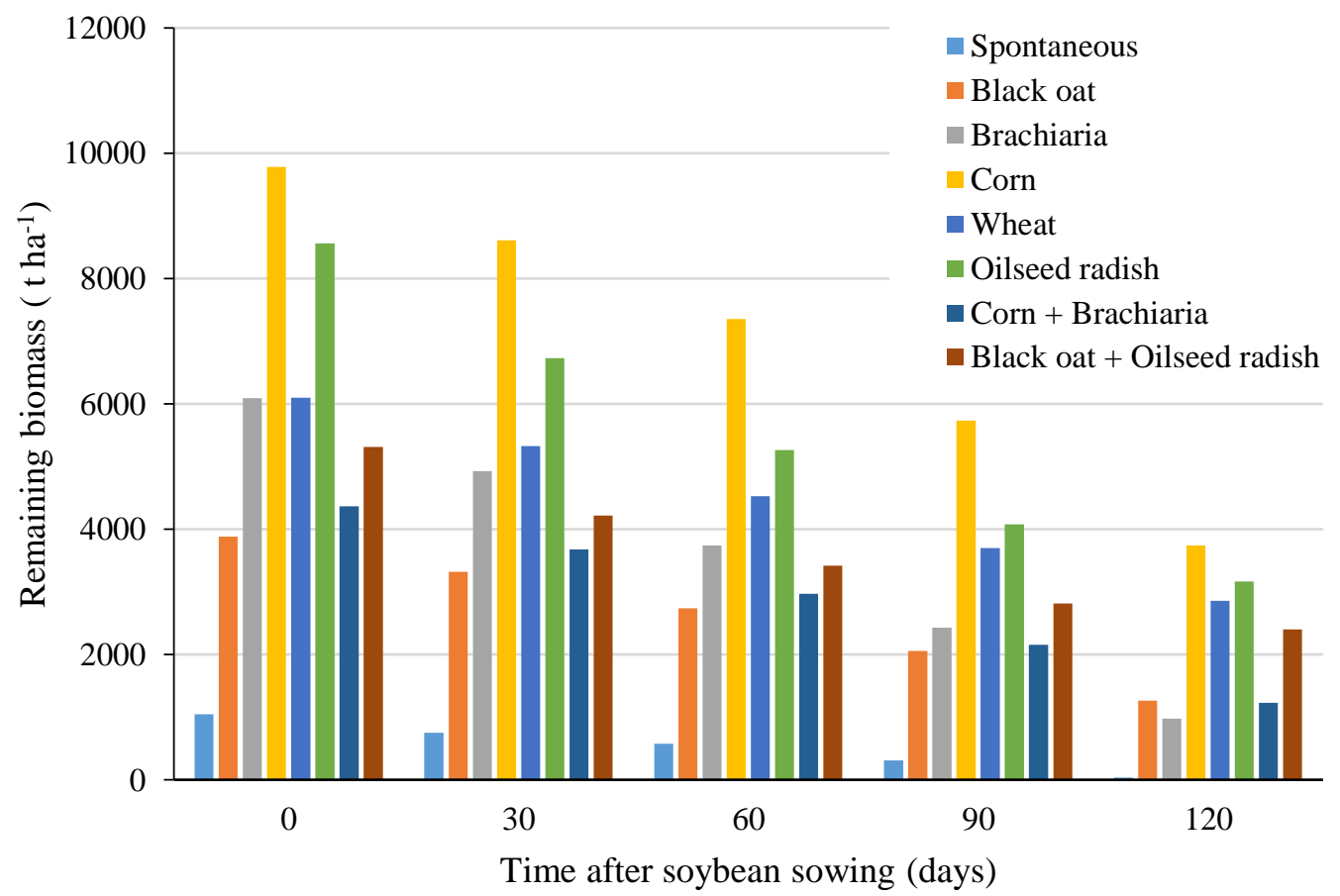

Figure 2. Straw remaining decomposition from the autumn/winter season during soybean development in the 2020/2021 harvest.

According to Costa et al. (2012), Kliemann et al. (2006), and Teixeira et al. (2011), the permanence of straw on the surface of the ground is a relevant factor to the maintenance and protection of the soil-plant system, benefiting the maintenance of moisture, favoring soil biota and nutrient cycling.

In the management of a no-till system, the knowledge of decomposition of remaining straw is fundamental for adopting practices that aim to increase the efficiency of the system. Also, in soils with low amounts of clay, the biomass produced interferes in the soil organic matter, generating physical, chemical, and biologicals benefits (Bonetti e Fink, 2020).

As discussed, the decomposition is influenced by environmental factors, being necessary news studies to compare the decomposition in different periods and producing regions, allowing to define management strategies aiming mainly for soil cover and nutrient cycling. 


\section{Conclusions}

The decomposition of the remaining biomass of agricultural species is influenced by environmental conditions, being different among crops. The wheat remaining straw showed the highest half-life time with the lowest decomposition rate.

The oilseed radish in single cultivation showed the highest production of biomass but with the highest decomposition rate. Intercropped systems reduce the decomposition rate of remaining biomass.

\section{Authors' Contribution}

Gustavo Soares Wenneck contributed to setup of experiment, writing, statistical analysis and revision. Reni Saath to the setup of experiment, technical supervision and revision. Larissa Leite de Araujo contributed to collection of data and to writing. Gustavo Lopes Pereira contributed to writing and revision. Roberto Rezende contributed to technical supervision and revision. Guilherme Soares Wenneck contributed to collection of data.

\section{Acknowledgments}

To the Fundação Agrisus (Project 2917/20), the Coordenação de Aperfeiçoamento de Pessoal de Nível Superior (CAPES), the Conselho Nacional de Desenvolvimento Científico e Tecnológico (CNPq), and the Fundação Araucária de Apoio ao Desenvolvimento Científico e Tecnológico do Estado do Paraná.

\section{Bibliographic References}

Aita, C., Giacomini, S.J. 2003. Decomposição e liberação de nitrogênio de resíduos culturais de plantas de cobertura de solo solteiras e consorciadas. Revista Brasileira de Ciência do Solo, 27 (4), 601-612. DOI: http://doi.org/10.1590/S010006832003000400004

Bonetti, J.A., Fink, J. 2020. Manejo e conservação do solo e da água, primeira ed. Editora UFLA, Lavras. http://repositorio.ufla.br/jspui/handle/1/45446 (acessado $20 \mathrm{de}$ julho de 2021).

Bueno, J.B., Rodrigues, G.A. 2019. Palha sobre o solo no crescimento da cultura do nabo forrageiro em área degradada. Interface Tecnológica, 16(1), 370-377. https://revista.fatectq.edu.br/index.php/interfacetecnologica/art icle/view/548 (acessado 20 de julho de 2021).

Cavalli, E., Lange, A., Cavalli, C., Behling, M. 2018. Decomposition and release of nutrients from crop residues on soybean-maize cropping systems. Revista Brasileira de Ciências Agrárias, 13 (2), e5527. DOI: https://doi.org/10.5039/agraria.v13i2a5527

Comin, J.J., Vilanova, C.C., Kurts, C., Muller Junior, V., Ventura, B.S., Reis, M.S., Brunetto, G., Lovato, P.E., Souza,
M. 2018. Avaliação fitossociológica de plantas invasoras em cultivo de cebola sob sistema plantio direto sem uso de agrotóxicos. Revista de la Facultad de Agronomia, 117(2), 197-206. https://revistas.unlp.edu.ar/revagro/article/view/7335 (acessado em 20 de julho de 2021).

Costa, N.R., Andreotti, M., Ulian, N.A., Costa, B.S., Pariz, C.M., Teixeira Filho, M.C.M. 2015. Acúmulo de nutrientes e tempo de decomposição da palhada de espécies forrageiras em função de épocas de semeadura. Bioscience Journal, 31(3), 818-829. DOI: https://doi.org/10.14393/BJ-v31n3a201522434

Costa, N.R., Andreotti, M., Gameiro, R.A., Pariz, C.M., Buzetti, S., Lopes, K.S.M. 2012. Adubação nitrogenada no consórcio de milho com duas espécies de braquiária em sistema plantio direto. Pesquisa Agropecuária Brasileira, 47(8), 1038-1047. DOI: https://doi.org/10.1590/S0100204X2012000800003

Cunha, T.J., Mendes, A.M.S., Iongo, V. 2015. Matéria orgânica do solo. In: Nunes, R.R., Rezende, M.O.O. (Ed.) Recurso solo: propriedades e usos. Editora Cubo, São Carlos, p. 273-293. http://www.iqsc.usp.br/iqsc/sites/recursosolo/LIVRO/livroRE CURSOSOLO.pdf (acessado 20 de julho de 2021).

Diniz, J.F., Oliveira, J.T., Borges, M.C.R.Z., Nogueira, K.B., Roque, C.G. 2019. Decomposição da palhada de Urochloa ruziziensis em diferentes sistemas de semeadura e correção do solo. Revista Engenharia na Agricultura, 27(4), 370-380. DOI: https://doi.org/10.13083/reveng.v27i4.957

Feitosa Júnior, F.R., Reis, D.A., Portella, R.B., Santos, J.R.S., Perina, F.J., Bogiani, J.C. 2019 Sistemas de manejo e parâmetros da matéria orgânica de um solo do cerrado baiano, Brasil. Revista Ibero Americana de Ciências Ambientais, 10(3), 298-312. DOI: https://doi.org/10.6008/CBPC21796858.2019 .003 .0025

Ferreira, D.F. 2019. SISVAR: a computer analysis system to fixed effects split plot type designs. Revista Brasileira de Biometria, 37(4), 529-535. DOI: https://doi.org/10.28951/rbb.v37i4.450

INMET. INSTITUTO NACIONAL DE METEOROLOGIA. Sistema de Suporte à Decisão na Agropecuária (SISDAGRO). http://sisdagro.inmet.gov.br/sisdagro/app/index (acessado 02 de fevereiro de 2021).

Kliemann, H.J., Braz, A.J.B.P., Silveira, P.M. 2006. Taxa de composição de resíduos de espécies de cobertura em Latossolo Vermelho Distroférrico. Pesquisa Agropecuária Tropical, 36(1), 21-28. https://www.revistas.ufg.br/pat/article/view/2165 (acessado 20 de julho de 2021).

Nitsche, P.R., Caramori, P.H., Ricce, W.S., Pinto, L.F.D. 2019. Atlás Climático do Estado do Paraná. IAPAR, Londrina. http://www.idrparana.pr.gov.br/system/files/publico/agromete orologia/iaas-climatico/atlas-climatico-do-parana-2019.pdf (acessado 20 de julho de 2021).

Pauletti, V., Motta, A.C.V. 2017. Manual de adubação e calagem para o estado do Paraná. Curitiba: SBCS/Nepar.

Ramos, D.D., Franco, L.T.S., Ajalla, A.C.A., Santos, D.G.B., Santos, F.A. 2018. Decomposição em diferentes espécies de leguminosas (Fabaceae). Cadernos de Agroecologia, 13(2), 1-8. http://cadernos.aba- 
agroecologia.org.br/index.php/cadernos/article/view/2021 (acessado 20 de julho de 2021).

Rossi, C.Q., Pereira, M.G., Giácomo, S.G., Betta, M., Polidoro, J.C. 2013. Decomposição e liberação de nutrientes da palhada de braquiária, sorgo e soja em áreas de plantio direto no cerrado goiano. Semina: Ciências Agrárias, 34(4), 1523-1534. http://www.uel.br/revistas/uel/index.php/semagrarias/article/vie w/10610/13043 (acessado 20 de julho de 2021).

Sakrezenski, E., Bordignon, E., Allebrandt, N., Sordi, A., Hicknman, C., Cericato, A. 2018. Rendimento e efeito residual da palhada de trigo (Triticum aestivum L.) na cultura da soja (Glycine $\max$ (L.) Merrill) cultivada em sucessão. Unoesc \& Amp; Ciência - ACET, 9(1), 67-76. http://portalperiodicos.unoesc.edu.br/acet/article/view/13126 (acessado 20 de julho de 2021).

Santos, H.G., Jacomine, P.K.T., Anjos, L.H. C., Oliveira, V.Á., Lumbreras, J.F., Coelho, M.R., Almeida, J.A., Araújo Filho, J.C., Oliveira, J.B., Cunha, T.J.F. 2018. Sistema Brasileiro de Classificação de Solos, quinta ed. EMBRAPA, Brasília. https://www.embrapa.br/solos/sibcs (acessado 20 de julho de 2021).

Silva, P.L.F., Oliveira, F.P., Pereira, W.E., Borba, J.O.M., Tavares, D.D., Santos, T.E.D., Martins, A.F. 2019. Estoques de carbono e retenção hídrica em biomassa de gramíneas no agreste da Paraíba. Brazilian Journal of Biosystems Engineering
13(2), 155-167. DOI: https://doi.org/10.18011/bioeng2019 v13n2p155-167

Sousa, I.R.L., Pauletto, D., Lopes, L.S.S., Rode, R. 2018. Decomposição de espécies utilizadas como adubação verde em sistema agroflorestal experimental, Santarém, Pará. Agroecossistemas, 10(2), 50-63. DOI: http://dx.doi.org/10.18542/ragros.v10i2.5202

Tavares, R. L. M.; Farhate, C. V. V.; Souza, Z. M.; La Scala Júnior, N.; Torres, J. L. R.; Campos, M. C. C. 2015. Emission of $\mathrm{CO}_{2}$ and soil microbial activity in sugarcane management systems. African Journal of Agricultural Research, 10 (9), 975-982. DOI: http://doi.org/10.5897/AJAR2014.9351

Teixeira, M.B., Loss, A., Pereira, M.G., Pimentel, C. 2011. Decomposição e liberação de nutrientes da parte aérea de plantas de milheto e sorgo. Revista Brasileira de Ciência do Solo, 35(3), 867-876. DOI: https://doi.org/10.1590/S010006832011000300021

Torres, J.L.R., Pereira, M.G., Fabian, A.J. 2008. Produção de fitomassa por plantas de cobertura e mineralização de seus resíduos em plantio direto. Pesquisa Agropecuária Brasileira, 43(3), 421-428. DOI: https://doi.org/10.1590/S0100204X2008000300018

Ziech, A.R.D., Conceição, P.C., Luchese, A.V., Balin, N.M., Candiotto, G., Garmus, T.G. 2015. Proteção do solo por plantas de cobertura de ciclo hibernal na região Sul do Brasil. Pesquisa Agropecuária Brasileira, 50 (5), 374-382 